\title{
Chemical and Biological Comparative in Vitro Studies of Cinnamon Bark and Lemon Peel Essential Oils
}

\author{
Eman M. Elgendy ${ }^{*}$, Hoda S. Ibrahim² ${ }^{2}$, Hanaa F. Elmeherry ${ }^{1}$, Amal G. Sedki', Faten U. Mekhemer ${ }^{3}$ \\ ${ }^{1}$ Department of Home Economy, Faculty of Specific Education, Mansoura University, Mansoura, Egypt \\ ${ }^{2}$ Department of Nutrition and Food Science, Faculty of Home Economics, Helwan University, Cairo, Egypt \\ ${ }^{3}$ Department of Home Economy, Faculty of Specific Education, Tanta University, Tanta, Egypt \\ Email: *eman_elgendy@hotmail.com
}

How to cite this paper: Elgendy, E.M., Ibrahim, H.S., Elmeherry, H.F., Sedki, A.G. and Mekhemer, F.U. (2017) Chemical and Biological Comparative in Vitro Studies of Cinnamon Bark and Lemon Peel Essential Oils. Food and Nutrition Sciences, 8, 110125.

http://dx.doi.org/10.4236/fns.2017.81008

Received: December 21, 2016

Accepted: January 17, 2017

Published: January 20, 2017

Copyright $\odot 2017$ by authors and Scientific Research Publishing Inc. This work is licensed under the Creative Commons Attribution International License (CC BY 4.0).

http://creativecommons.org/licenses/by/4.0/ (c) (7) Open Access

\begin{abstract}
Cinnamon and lemon are the oldest plants which possess a rising popularity due to their therapeutic potential from centuries. Cinnamomum zeylanicum and lemon (Citrus lemon L.) have been subjected to extensive research. Their essential oils were extracted by steam distillation from selected plants and their chemical compositions were determined by the GC-MS system. Cinnamon and lemon essential oils were examined for antioxidant activity by ABTS method which showed the ability to inhibit lipid per-oxidation. On the other hand, in antimicrobial investigations, cinnamon and lemon essential oils have inhibitory effect against Gram positive bacteria (Staphylococcus aureus) and Gram negative bacteria (Escherichia coli) using Muller Hinton agar medium. The essential oils of cinnamon and lemon showed antifungal effects which were tested against (Candida albicans). The volatile oil of cinnamon bark has been found to be highly effective against all the tested bacteria and fungi. However, lemon peel essential oil has shown medium inhibition for Gram positive bacteria (Staphylococcus aureus). On the other hand, the cytotoxic activities of the essential oils were tested on hepatocellular carcinoma and colorectal carcinoma. Essential oils have shown good activities on the cell lines. Essential oil of cinnamon showed more inhibition rate than essential oil of lemon. This study reported the importance of both cinnamon and lemon volatile oils and recommends that cinnamon and lemon can be used as an active therapy for humans.
\end{abstract}

Keywords

Cinnamon, Lemon, Essential Oil, Cinnamaldehyde, Limonene

\section{Introduction}

Many pathways have been done to keep our food healthy. One pathway to inhibit food 
spoilage is adding preservatives such as antioxidant, antifungal and antimicrobial substances to food. Artificial preservatives, is one of the oldest techniques which play an important role as antimicrobial, antifungal and antioxidant, but have adverse effects on health [1].

Natural additives are widespread due to health problems caused by different artificial preservatives [2] [3].

Using plants and materials of plant origin such as essential oils, is a suitable way to increase safety, quality and nutritional values for food products [4] [5]. Essential oils obtained from plants are used in many foodstuffs to increase their shelf-life [6]. Essential oils are mixture of volatile compounds with intense scent that are synthesized in several plant organs, including flowers, leaves, fruits, or bark, and stored in epidermis cells [7] [8]. These volatile compounds act as protective substances against microorganisms and herbivores [9]. Essential oils are used as carminative, stomachic, stimulant, aromatic, antiseptic [10] and as a flavoring agent in beverages, foods, cosmetics, and household products [11]. Phenolic compounds and terpenes are the main biologic constituents in the volatile oils [12] [13] [14].

Cinnamon, essential oil is obtained from Cinnamomum zeylanicum (Lauraceae), plant. The important constituents of cinnamon essential oil are cinnamaldehyde (60-70\%), eugenol (5\% - 10\%), benzaldehyde, cuminaldehyde [15] [16]. Lemon essential oil (Citrus lemon L.) from fruit peel contains limonene, beta pinene and gama terpinene [11]-[17]. Our study has prompted us to describe the chemical composition of cinnamon and lemon essential oils, to explore and compare their antioxidant, antifungal, antibacterial, antifungal, antioxidant and anticancer activities.

\section{Materials and Methods}

\subsection{Plant Materials}

Cinnamon, Cinnamomum zeylanicum Nees (Lauraceae) and Lemon Citrus limonum L. were bought from a native market in Egypt. Plant materials consisted of stem bark (cinnamon) and fruit peel (lemon).

Chemical reagents: All the chemicals and solvents were of pro-analysis purity and were obtained from Sigma (Sigma-Aldrich GmbH, Sternheim, Germany). Gram positive bacteria (Staphylococcus aureus), Gram negative bacteria (Escherichia coli) and (Candida albicans) fungi were obtained from department of pharmacology, Faculty of Pharmacy, Mansoura University. Hepatocellular carcinoma (HePG-2) and colorectal carcinoma (HCT-116) cell lines were obtained from ATCC via Holding company for biological products and vaccines (VACSERA), Cairo, Egypt. The reagents RPMI-1640 medium, MTT, DMSO and 5-fluorouracil (Sigma Co., St. Louis, USA), Fetal Bovine serum (GIBCO, UK).

\subsection{Separation of Essential Oils}

Five hundred grams of dried plant material was subjected to three-hours of steam distillation or steam distillation using a Clevenger-type apparatus. The gained essential oils were dried over anhydrous sodium sulphate and stored in locked and dark bottle at $-18^{\circ} \mathrm{C}$ till needed. 


\subsection{Gas Chromatography-Mass Spectrometry}

Volatile essential oils were analyzed by injecting $1 \mathrm{ul}$ sample to GC/MS system "Focus/DSQ II" (Thermo Scientific, USA). Focus Gas chromatograph equipped with nonpolar column (5\% phenyl polysilphenylene-siloxane): Thermo-TR.5MS with dimensions $30 \mathrm{~m}$ length and inner diameter $0.25 \mathrm{~mm}$ with film thickness $0.25 \mathrm{um}$ ) The column hold at $60^{\circ} \mathrm{C}$ for $5 \mathrm{~min}$ and heated with rate $5^{\circ} \mathrm{C} / \mathrm{min}$ to final temperature $260^{\circ} \mathrm{C}$ and hold to $5 \mathrm{~min}$. He was used as carrier gas with flow rate $1.2 \mathrm{ml} / \mathrm{min}$, the injection port temperature hold at $250^{\circ} \mathrm{C}$. The transfer line and ion source temperatures were $280^{\circ} \mathrm{C}$. Ionization of sample components was performed in the EI mode with $(70 \mathrm{eV})$.

\subsection{Components Identification}

The components of essential oil were identified on the basis of comparison of their retention indices and mass spectra with published data [18] [19] and computer matching with WILEY 275 and National Institute of Standards and Technology (NIST 3.0) libraries provided with computer controlling the GC-MS system. The results were also confirmed by the comparison of the compounds elution order with their relative retention indices on non-polar phase reported in the literature [18]. The retention indices were calculated for all volatile constituents using a homologous series of n-alkanes C8 - C16.

\subsection{Determination of Antioxidant Activity with the 2,2'-Azino-Bis(3-ethyl benzthiazoline-6-sulfonic acid) (ABTS) Assay}

ABTS solution ( $2 \mathrm{~mL}$ of $60 \mathrm{mM}$ ) was added to each of the two essential oils then $\mathrm{MnO}_{2}$ solution $(25 \mathrm{mg} / \mathrm{mL}$ of $3 \mathrm{M})$ in phosphate buffer $(\mathrm{pH} 7,0.1 \mathrm{M})$. The blend was shaken, centrifuged, filtered. The absorbance (A control) of the resulting green-blue solution (ABTS radical solution) was regulated at ca. 0.5 at $1734 \mathrm{~nm}$. Then, $50 \mathrm{ml}$ of $(2 \mathrm{mM})$ solution of the two oils in spectroscopic grade $\mathrm{MeOH} /$ phosphate buffer (1:1) was added. The absorbance (A test) was measured and the lowering in color sharpness was expressed as $\%$ inhibition. The $\%$ inhibition for each oil is calculated from the following equation [20].

$$
\text { \%Inhibition }=(\text { A control }- \text { A test }) / \text { A control } \times 100
$$

Ascorbic acid (vitamin C) was applied as standard anti-oxidant (positive control). Blank sample was take place without ABTS and using $\mathrm{MeOH} /$ phosphate buffer (1:1) instead of sample. Negative control sample was carried out with $\mathrm{MeOH} / \mathrm{phosphate} \mathrm{buf-}$ fer (1:1) instead of oil.

\subsection{In Vitro Anti-Microbial Activity Evaluation}

Staphylococcus aureus and Escherichia coli were used to determine the anti-bacterial activity of each essential oil under study using Muller Hinton agar medium. The anti-fungal activity of the studied essential oils was tested against Candida albicans using Sabouraud dextrose agar medium. The anti-bacterial and anti-fungal activities were determined by agar streak dilution method. This method was conducted according to the method of Hawkey and Lewis (1994) [21]. Ciprofloxacin and Fluconazole were used 
as standard for anti-bacterial and anti-fungal activities, respectively. The lowest concentration of each essential oil under study, which did not show any growth of tested microorganisms after macroscopic evaluation was determined as the minimal inhibitory concentration (MIC) of this oil.

\subsection{In Vitro Cytotoxicity Activity Evaluation}

Hepatocellular carcinoma (HePG-2) and colorectal carcinoma (HCT-116) cell lines were used to determine the inhibitory effect of each essential oil under study on cell growth using the 3-(4,5-dimethylthiazol-2-yl)-2,5-diphenyl tetrazolium bromide (MTT) assay. The MTT method was conducted according to the colorimetric method of Mosmann (1983) [22]. 5-Fluorouracil was used as a standard anticancer drug for comparison. The relative cell viability in percentage was calculated as follows:

Relative cell viability \%

$=($ Absorbance of treated cells/Absorbance of untreated cells $) \times 100$

IC50 value of tested essential oil is the concentration of the tested essential oil that would result in the death of $50 \%$ of the cells.

\subsection{Statistical Analysis}

Statistical analysis was done using GraphPad Prism version 3.0 for windows (GraphPad Prism, 1999) [23]. The majority of the data presented in this study reflect the means \pm deviation (SD). One way analysis of variance (ANOVA) and the Tukey's Multiple Comparison Test were used to determine the differences among the means. The significant difference was set at $P<0.05$.

\section{Results and Discussion}

\subsection{Phytochemical Analysis}

Phytochemical analysis of Cinnamomum zeylanicum L. bark essential oil demonstrates the presence with high percent of phenols and terpenoids. Whereas, analysis of Citrus lemon $L$. fruit peel essential oil proved the presence of, terpenoids with high percent [24]. Essential oils are naturally volatile substances, existing in different parts (flowers, leaves, seeds, roots, bark) of all plants with strong aroma. The amount of essential oils in plants different from very small amounts $(0.05 \%-0.1 \%)$ in one while in other up to $20 \%[25]$.

Cinnamon bark essential oil obtained by steam distillation. Its yield was found to be $1.5 \%$. The gas chromatography technique of Cinnamon essential oil detected the presence of many substances which could be identified. It has been found main peak at retention time (RT) $16.80 \mathrm{~min}$. with a relative abundance of $64.84 \%$ and the molecular formula $\mathrm{C}_{9} \mathrm{H}_{8} \mathrm{O}$ and molecular weight $(\mathrm{M} . w \mathrm{wt}=132.16)$. The expected substance is trans-cinnamaldehyde (Figure 1). Trans-Cinnamaldehyde [3-phenyl-propenal, II] is the major component of essential oil of cinnamon and its fragments are $132(\mathrm{M})^{+}, 131$ $(\mathrm{M}-1)^{+}, 115(\mathrm{M}-1-\mathrm{O})^{+}, 103(\mathrm{M}-\mathrm{CHO})^{+}, 91\left(\mathrm{M}-\mathrm{C}_{2} \mathrm{HO}\right)^{+}$and $77\left(\mathrm{C}_{6} \mathrm{H}_{5}\right)^{+}$, with base peak $131 \mathrm{~m} / \mathrm{z}$. The complete list of the ingredients and their relative abundances are presented in Table 1. 


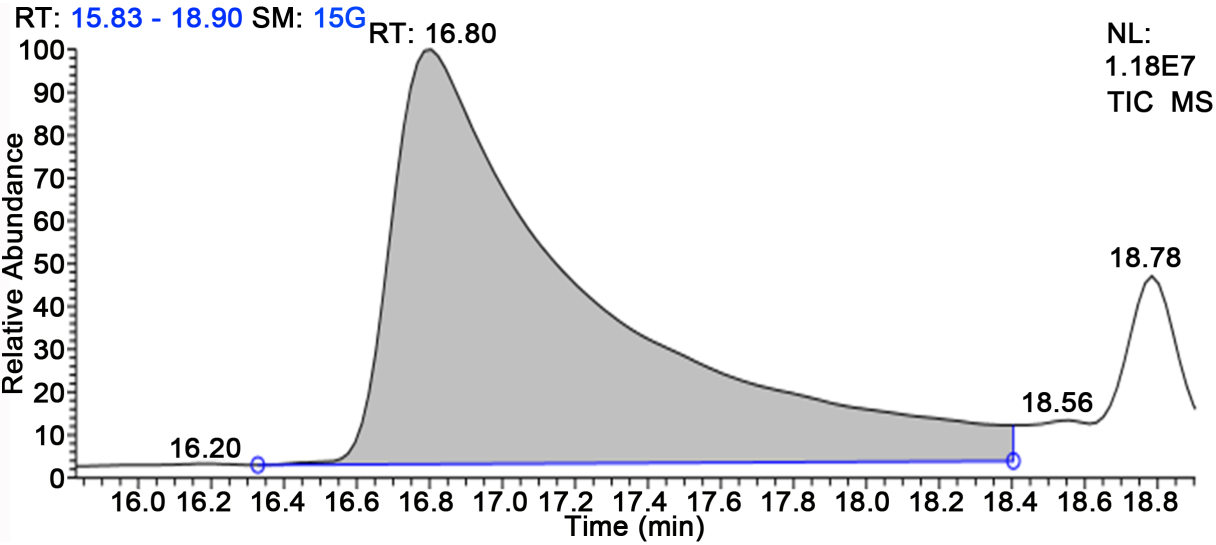

Figure 1. Chromatogram of the main component (trans-cinnamaldehyde) of cinnamon essential oil by GC-MS.

Table 1. Chemical composition of cinnamon essential oil.

\begin{tabular}{|c|c|c|c|}
\hline $\begin{array}{c}\text { Retention } \\
\text { time (min) }\end{array}$ & $\begin{array}{l}\text { Molecular } \\
\text { formula }\end{array}$ & Compound & $\begin{array}{c}\text { Area } \\
\%\end{array}$ \\
\hline 3.78 & $\mathrm{C}_{8} \mathrm{H}_{10}$ & Ethyl benzene & 1.50 \\
\hline 16.8 & $\mathrm{C}_{9} \mathrm{H}_{8} \mathrm{O}$ & trans-cinnamaldehyde & 64.84 \\
\hline 18.56 & $\mathrm{C}_{15} \mathrm{H}_{24}$ & $\begin{array}{c}\text { 1,2,4-Metheno-1H-indene, } \\
\text { octahydro-1,7 } \alpha \text {-dimethyl-5-(1-methylethyl) }\end{array}$ & 1.90 \\
\hline 18.78 & $\mathrm{C}_{15} \mathrm{H}_{24}$ & Copaene & 8.48 \\
\hline 19.03 & $\mathrm{C}_{10} \mathrm{H}_{12} \mathrm{O}_{2}$ & Eugenol & 6.72 \\
\hline 20.23 & $\mathrm{C}_{15} \mathrm{H}_{24}$ & Caryophyllene & 2.01 \\
\hline 21.43 & $\mathrm{C}_{15} \mathrm{H}_{24}$ & $4 \alpha \mathrm{H}, 5 \alpha$-Eremophila-1(10),11-diene & 0.37 \\
\hline 21.98 & $\mathrm{C}_{15} \mathrm{H}_{24}$ & Copaene & 1.32 \\
\hline 22.75 & $\mathrm{C}_{15} \mathrm{H}_{24}$ & Cadina-4,9-diene & 3.09 \\
\hline 23.34 & $\mathrm{C}_{15} \mathrm{H}_{24}$ & Cadina-3,9-diene & 4.46 \\
\hline 24.19 & $\mathrm{C}_{15} \mathrm{H}_{22}$ & Cadala-1(10),3,8-triene & 0.44 \\
\hline 27.41 & $\mathrm{C}_{15} \mathrm{H}_{24}$ & $\alpha$-Guaiene & 0.80 \\
\hline 28.27 & $\mathrm{C}_{15} \mathrm{H}_{18}$ & Azulene, 1,4-dimethyl-7-(1-methylethyl)- & 0.32 \\
\hline 29.41 & $\mathrm{C}_{19} \mathrm{H}_{26} \mathrm{O}_{6}$ & $\begin{array}{l}\text { Propanoic acid, 2-methyl-, } \\
\text { (decahydro-6 } \alpha \text {-hydroxy-9 } \alpha \text {-methyl-3-methylene-2,9- } \\
\text { dioxoazuleno[4,5- } \beta] \text { furan-6-yl)methyl ester, }\end{array}$ & 0.18 \\
\hline 29.92 & $\mathrm{C}_{26} \mathrm{H}_{33} \mathrm{NO}_{2}$ & Fenretinide & 0.40 \\
\hline \multirow[t]{2}{*}{$35.94-41.27$} & $\mathrm{C}_{35} \mathrm{H}_{70}$ & 17-Pentatriacontene & 3.19 \\
\hline & & Total identified & $100 \%$ \\
\hline
\end{tabular}

Elgendy and Khayyat, 2014 have been proved that trans cinnamaldehyde can act as antioxidants. It was trapped the reactive oxygen species (ROS) to give the intermediated epoxides and hydroperoxide derivatives [26].

Lemon essential oil is a complex organic compound isolated from citrus fruit peel, through steam distillation process. The yield of its oil was found to be around $1.9 \%$. 
The gas chromatography technique of Lemon oil discovered the presence of many substances which could be identified. It has been found main peak at retention time (RT) $7.72 \mathrm{~min}$, with a relative abundance of $86.95 \%$ and the molecular formula $\mathrm{C}_{10} \mathrm{H}_{16}$ and molecular weight (M.wt $=136.24)$ (Figure 2$)$. The expected substance is d-Limonene (1-methyl-4-(1-methylethenyl)-cyclohexene IV), is the major component of Lemon es-

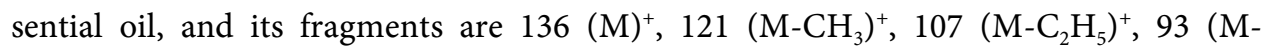
$\left.\mathrm{C}_{3} \mathrm{H}_{7}\right)^{+}$and $79\left(\mathrm{C}_{6} \mathrm{H}_{7}\right)^{+}$, with base peak $93 \mathrm{~m} /$ z. The complete list of the ingredients and their relative abundances are presented in Table 2.

Elgendy, 1998 has been proved that Limonene can act as antioxidants. It was trapped the reactive oxygen species (ROS) to give the intermediated hydroperoxide derivative [27].

Table 2. Chemical composition of lemon oil.

\begin{tabular}{|c|c|c|c|}
\hline Retention time (min) & Molecular formula & Compound & Area \% \\
\hline 3.65 & $\mathrm{C}_{16} \mathrm{H}_{34} \mathrm{O}$ & 2-Hexadecanol & 0.08 \\
\hline 5.02 & $\mathrm{C}_{10} \mathrm{H}_{16}$ & 3-Carene & 0.45 \\
\hline 6.45 & $\mathrm{C}_{10} \mathrm{H}_{16}$ & $\alpha$-Pinene & 0.45 \\
\hline 6.96 & $\mathrm{C}_{10} \mathrm{H}_{16}$ & $\alpha$-Phellandrene & 4.59 \\
\hline 7.72 & $\mathrm{C}_{10} \mathrm{H}_{16}$ & D-Limonene & 86.95 \\
\hline 9.40 & $\mathrm{C}_{10} \mathrm{H}_{16}$ & $\rho$-Mentha-1,4(8)-diene & 0.19 \\
\hline 10.14 & $\mathrm{C}_{10} \mathrm{H}_{18} \mathrm{O}$ & cis-Geraniol & 0.33 \\
\hline 10.83 & $\mathrm{C}_{10} \mathrm{H}_{16}$ & Allo-Ocimene & 1.28 \\
\hline 11.74 & $\mathrm{C}_{10} \mathrm{H}_{18} \mathrm{O}$ & $\alpha$-Citronellal & 1.16 \\
\hline 12.84 & $\mathrm{C}_{10} \mathrm{H}_{18} \mathrm{O}$ & Isoborneol & 0.35 \\
\hline 13.45 & $\mathrm{C}_{10} \mathrm{H}_{18} \mathrm{O}$ & $\rho$-Menth-1-en-8-ol & 3.10 \\
\hline 14.94 & $\mathrm{C}_{13} \mathrm{H}_{22} \mathrm{O}_{2}$ & $\alpha$-Terpinyl propionate & 0.08 \\
\hline 16.10 & $\mathrm{C}_{10} \mathrm{H}_{16} \mathrm{O}$ & $\alpha$-Citral & 0.13 \\
\hline 18.78 & $\mathrm{C}_{15} \mathrm{H}_{24}$ & Copaene & 0.05 \\
\hline 20.23 & $\mathrm{C}_{15} \mathrm{H}_{24}$ & Caryophyllene & 0.05 \\
\hline 21.45 & $\mathrm{C}_{28} \mathrm{H}_{48} \mathrm{O}$ & Cholestan-3-ol, 2-methylene-, & 0.05 \\
\hline 22.23 & $\mathrm{C}_{15} \mathrm{H}_{26} \mathrm{O}$ & Longiborneol & 0.16 \\
\hline 22.55 & $\mathrm{C}_{15} \mathrm{H}_{24}$ & $4 \alpha \mathrm{H}, 5 \alpha$-Eremophila-1(10),11-diene & 0.21 \\
\hline 23.33 & $\mathrm{C}_{15} \mathrm{H}_{24}$ & $\alpha$-Guaiene & 0.09 \\
\hline 31.18 & $\mathrm{C}_{10} \mathrm{H}_{16}$ & Allo-Ocimene & 0.03 \\
\hline 34.85 & $\mathrm{C}_{30} \mathrm{H}_{50} \mathrm{O}_{2}$ & Betulin & 0.04 \\
\hline 35.73 & $\mathrm{C}_{30} \mathrm{H}_{50} \mathrm{O}$ & Lupeol & 0.04 \\
\hline 36.13 & $\mathrm{C}_{20} \mathrm{H}_{28} \mathrm{O}_{6}$ & $\begin{array}{c}\text { 1H-2,8 } \alpha \text {-Methanocyclopenta[a] } \\
\text { cyclopropa[e]cyclo-decen-11-one }\end{array}$ & 0.06 \\
\hline \multirow[t]{2}{*}{36.76} & $\mathrm{C}_{20} \mathrm{H}_{28} \mathrm{O}_{3}$ & $6 \alpha$-Hydroxymethandienone & 0.06 \\
\hline & & Total identified & $100 \%$ \\
\hline
\end{tabular}




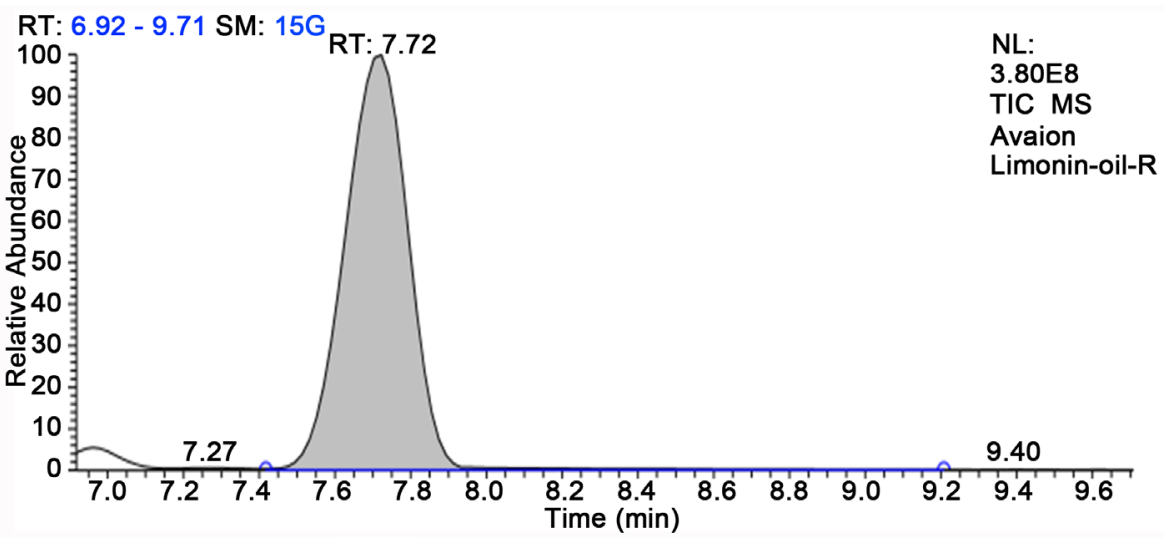

Figure 2. Chromatogram of the main component (Limonene) of lemon essential oil by GC-MS.

\subsection{Antioxidant Activity of Essential Oils}

It is recognized that free radicals are implicated in the lipid per-oxidation reactions and represent a major role in many chronic diseases such as heart and cancer diseases [28]. Therefore, the capability to scavenge free radicals is an important antioxidant feature to decrease cell damage. In many studies in vitro the essential oils exhibited noticeable antioxidant activity [29] [30].

\section{Choice of the Method for Determination of Antioxidant Activities}

Estimation of antioxidant activity needs use of different methods [31] [32]. ABTS, RANCIMAT and TBARS can be quoted as comparatively simple methods that can be used to gauge the antioxidant activity of essential oils [33]-[39].

TBARS assay cannot evaluate the antioxidant activity of cinnamon essential oil, because trans-cinnamaldehyde is the main component of oil, which strongly interacted with the thiobarbituric acid used in the assay, developing a yellow color [40].

On the other hand, although the RANCIMAT test is commonly used in the food industry and governmental analytical laboratories [41] [42], RANCIMAT test is not convenient for such measurement, because air inserted inside hot systems (oil) during measurement evaporates essential oils samples formerly and retards measurements.

\subsection{Anti-0xidant Activity Screening Assay ABTS}

Antioxidant activities of essential oils from redolent plants are due to the active or major constituents, in them. This may be also, due to the minor constituents among them [43]. In this study, the antioxidant activities are determined. It has been suggested that the two essential oils, i.e., cinnamon and lemon, could be used as a prospective origin of natural antioxidants with wide applications in food products. The antioxidant activity of cinnamon and lemon essential oils are mainly due to the high content of cinnamaldehyde and limonene respectively. The Stronger activity is indicated by a higher antioxidant index determined by ABTS method. Cinnamon and lemon essential oils were examined for antioxidant activity which showed the ability to inhibit lipid per-oxidation. They proved powerful anti-oxidative activity in the lipid per-oxidation test. The results are summarized in Table 3.

Cinnamon and lemon oils have antioxidant activities. Cinnamon oil showed higher inhibitory anti-oxidant activity than lemon oil (Figure 3). 


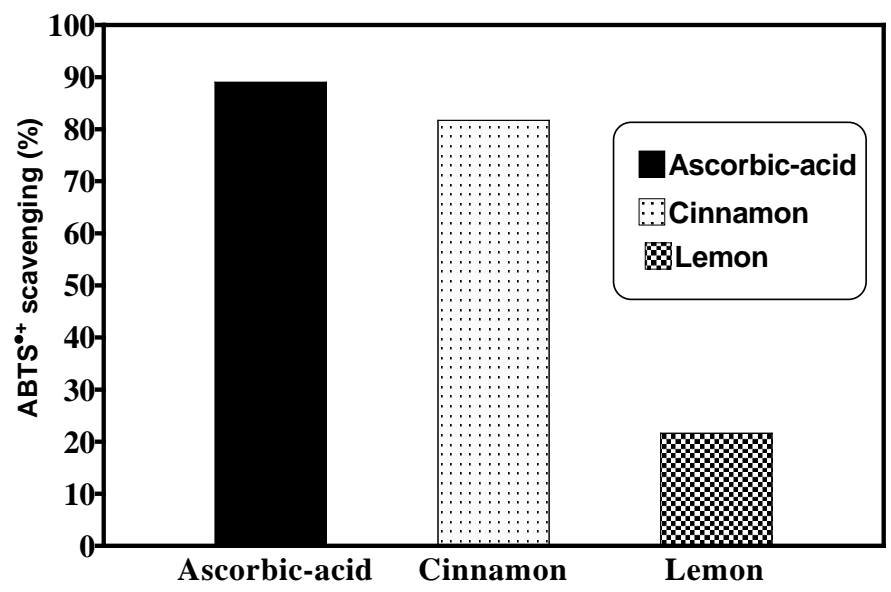

Figure 3. Anti-oxidant activity screening of the essential oils under study by ABTS method.

Table 3. Anti-oxidant activity screening of the essential oils under study by ABTS method.

\begin{tabular}{ccc}
\hline \multirow{2}{*}{ Sample } & 2,2'-azino-bis(3-ethyl benzthiazoline-6-sulfonic acid) (ABTS) \\
\cline { 2 - 3 } & Absorbance & ${ }^{*}$ ABTS $^{*+}$ scavenging (\%) \\
\hline Control of ABTS & 0.508 & - \\
$* *$ Ascorbic-acid & 0.056 & $89.0 \%$ \\
Cinnamon oil & 0.093 & $81.7 \%$ \\
Lemon oil & 0.398 & $21.6 \%$ \\
\hline
\end{tabular}

${ }^{*} \mathrm{ABTS}^{*+}$ scavenging $(\%)=(1-$ absorbance of sample at $734 \mathrm{~nm} /$ absorbance of control at $734 \mathrm{~nm}) \times 100 \%$;

${ }^{*}$ Ascorbic acid (vitamin C) was used as standard anti-oxidant (positive control).

\subsection{Antimicrobial and Antimycotic Activities in Terms of MIC $(\mu \mathrm{g} / \mathrm{mL})$}

\section{Anti-Microbial Activity Evaluation in Vitro}

Essential oils of cinnamon and lemon submit the potential not only to resist infection, but also to prevent the outgrowth of microbe.

Cinnamon bark essential oil has cinnamaldehyde as a major ingredient was chosen for this study due to its various chemical compositions. Lemon citrus peel essential oil has limonene as a major ingredient was chosen for comparative study between them. According to Inouye et al., essential oil of cinnamon bark has antibacterial effects on major respiratory pathogens such as Streptococcus pneumoniae and Streptococcus pyogenes [44] [45].

Cinnamon and lemon essential oils have strong inhibitory effect against Gram positive bacteria (Staphylococcus aureus) and Gram negative bacteria (Escherichia coli) using Muller Hinton agar medium (Oxoid) [46]. On the other hand, The essential oils of cinnamon, and lemon showed antifungal effects which were tested against (Candida albicans). The lowest concentration of each essential oil under study, which did not show any growth of tested microorganisms after macroscopic evaluation, was determined as the minimal inhibitory concentration (MIC) of this oil. Comparative study has been done of the antimicrobial activities of cinnamon and lemon essential oils. The results were obtained in Figure 4 and Figure 5.

Cinnamon essential oil demonstrated larger effect than lemon. Lemon peel essential 


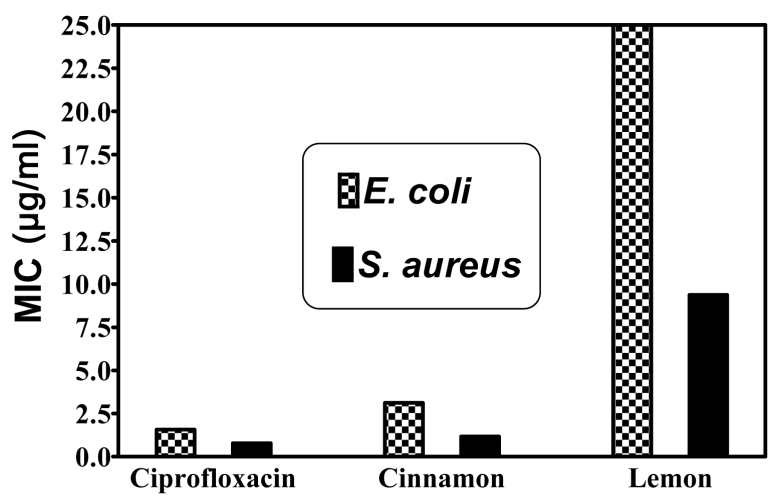

Figure 4. Effect of the essential oils under study on Escherichia coli and Staphylococcus aureus.

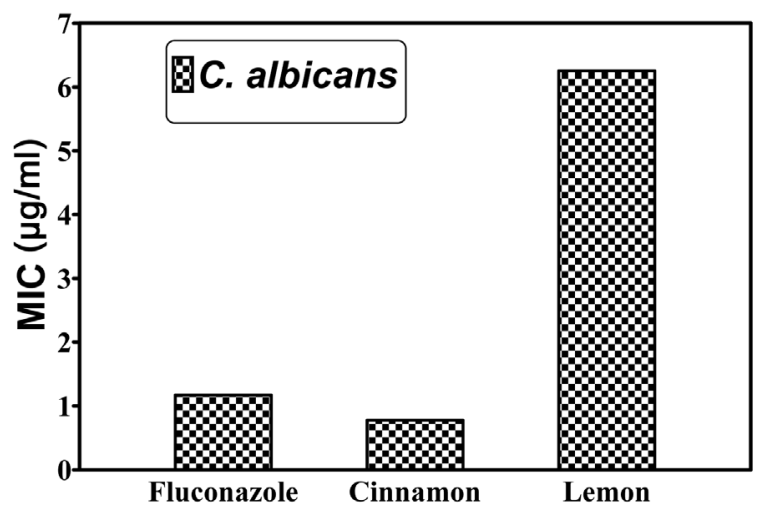

Figure 5. Effect of the essential oils under study on Candida albicans.

oil has shown good inhibition only for Gram positive bacteria (Staphylococcus aureus). Ciprofloxacin and Fluconazole were used as standard for anti-bacterial and anti-fungal activities, respectively (Table 4).

Cytotoxicity Assay

Hepatoprotective Activity Evaluation in Vitro:

Cell Cultures and Anti-Proliferative Activity Assay

A great feature of essential oils if they used on a long-term, is not associated with genotoxic risk. Some of them have antimutagenic activity that could well be connected to an anticarcinogenic activity [47].

Hepatocellular carcinoma (HePG-2) and colorectal carcinoma (HCT-116) are perennial cell line used in scientific study. They are the most popular applied human cell lines [48] [49]. The cytotoxic activities of the essential oils were tested on Hepatocellular carcinoma and colorectal carcinoma. Essential oil submitted good activities on the cell lines. Essential oil of cinnamon showed more inhibition rate than essential oil of lemon (Tables 5-7 and Figures 6-9).

The IC50 values against HePG2 indicated that the cytotoxicity of each essential oil decreased when their concentration increase. IC50 value of cinnamon essential oil was very strong whereas, IC50 value of lemon essential oil was moderate. On the other hand, The IC50 values against HCT-116 indicated that it was very strong in case of cinnamon essential oil, whereas, in case of lemon essential oil, it was weak (Table 8 and Figure 10). 


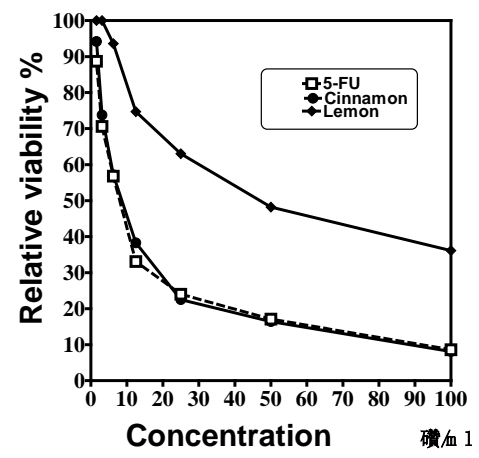

Figure 6. Effect of the essential oils under study on relative viability \% of hepatocellular carcinoma cell line (HePG-2).

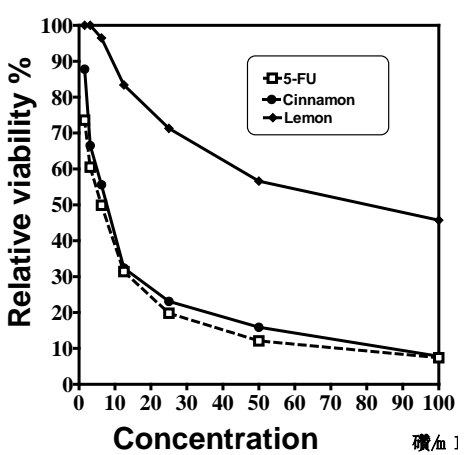

Figure 7. Effect of the essential oils under study on relative viability \% of colorectal carcinoma cell line (HCT-116).

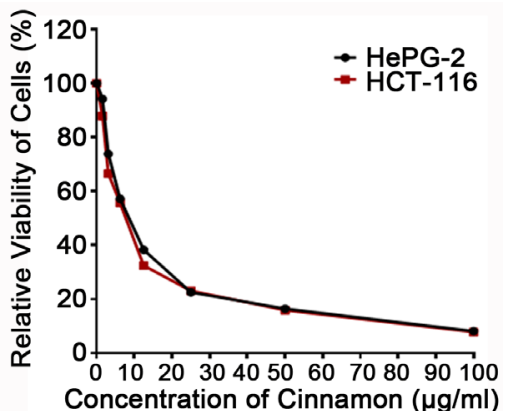

Figure 8. Effect concentration of cinnamon essential oil on relative viability \% of hepatocellular carcinoma cell line (HePG-2) and colorectal carcinoma cell line (HCT-116).

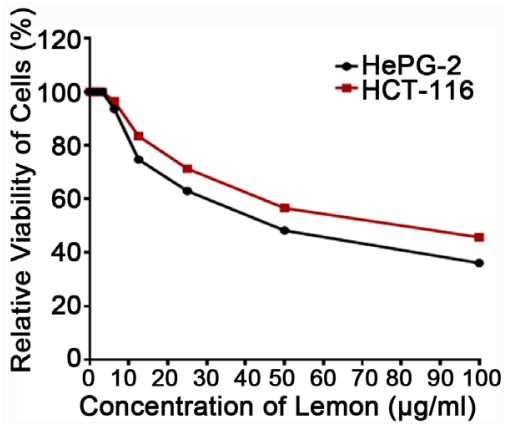

Figure 9. Effect concentration of lemon essential oil on relative viability \% of Hepatocellular carcinoma cell line (HePG-2) and colorectal carcinoma cell line (HCT-116). 
HePG2

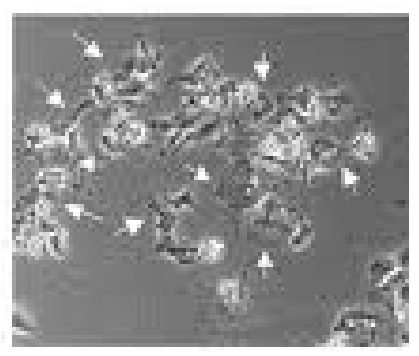

HCT-116

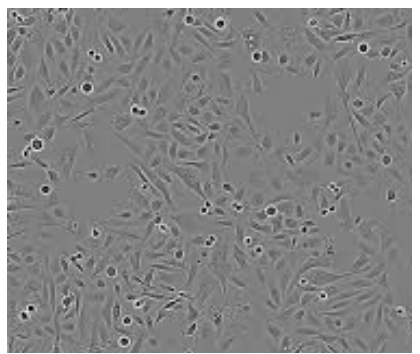

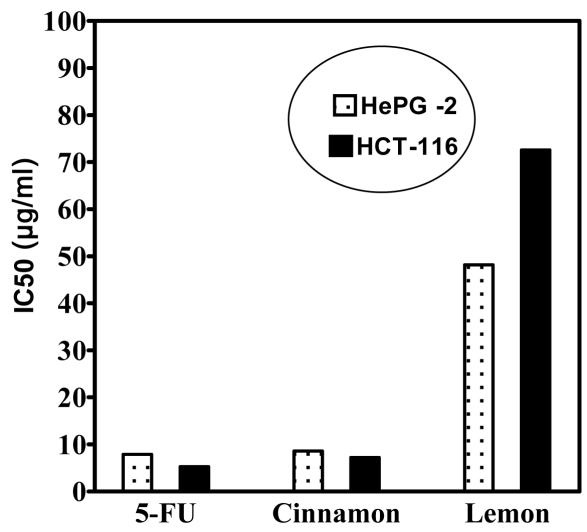

Figure 10. Cytotoxic activity of the essential oils under study against colorectal carcinoma (HCT$116)$ and hepatocellular carcinoma (HePG-2) cell lines. IC50 $(\mu \mathrm{g} / \mathrm{ml}): 1$ - 10 (very strong), 11 - 20 (strong), 21 - 50 (moderate), 51 - 100 (weak).

Table 4. Antimicrobial activity of the tested essential oils.

\begin{tabular}{cccc}
\hline \multirow{2}{*}{ Sample } & \multicolumn{3}{c}{ Minimum inhibitory concentration MIC $(\mu \mathrm{g} / \mathrm{ml})$} \\
\cline { 2 - 4 } & E. coli & S. aureus & C. albicans \\
\hline Cinnamon oil & 3.12 & 1.17 & 0.78 \\
Lemon oil & 25.0 & 9.37 & 6.25 \\
Ciprofloxacin & 1.56 & 0.78 & $\ldots$ \\
Fluconazole & $\ldots$ & $\ldots$ & 1.17 \\
\hline
\end{tabular}

Table 5. Relative viability \% of hepatocellular carcinoma cell line (HePG-2) and colorectal carcinoma cell line (HCT-116) after treating by the tested essential oils.

\begin{tabular}{ccccccc}
\hline \multirow{2}{*}{$\begin{array}{c}\text { Concentration } \\
\mu \mathrm{g} / \mathrm{ml}\end{array}$} & \multicolumn{2}{c}{ 5-FU } & \multicolumn{2}{c}{ Cinnamon oil } & \multicolumn{2}{c}{ Lemon oil } \\
\cline { 2 - 6 } & HePG-2 & HCT-116 & HePG-2 & HCT-116 & HePG-2 & HCT-116 \\
\hline 100 & $\mathbf{8 . 6}$ & 7.4 & $\mathbf{8 . 1}$ & 7.8 & 36.1 & 45.7 \\
50 & 17.1 & 12.1 & 16.4 & 15.9 & 48.2 & 56.6 \\
25 & 24.0 & 19.8 & 22.5 & 23.1 & 63.0 & 71.3 \\
12.5 & 33.1 & 31.4 & 38.3 & 32.4 & 74.7 & 83.4 \\
6.25 & $\mathbf{5 6 . 8}$ & 49.9 & $\mathbf{5 7 . 2}$ & 55.6 & 93.6 & 96.5 \\
3.125 & 70.6 & 60.5 & 73.8 & 66.5 & 100 & 100 \\
1.56 & $\mathbf{8 8 . 7}$ & 73.6 & 94.2 & 87.8 & 100 & 100 \\
\hline
\end{tabular}

5-FU: 5-Fluorouracil was used as a standard anticancer drug for comparison. 
Table 6. Relative viability \% of hepatocellular carcinoma cell line (HePG-2) after treating by the tested essential oils.

\begin{tabular}{cccc}
\hline Concentration $\mu \mathrm{g} / \mathrm{ml}$ & 5 -FU & Cinnamon essential oil & Lemon essential oil \\
\hline 100 & 8.6 & 8.1 & 36.1 \\
50 & 17.1 & 16.4 & 48.2 \\
25 & 24.0 & 22.5 & 63.0 \\
12.5 & 33.1 & 38.3 & 74.7 \\
6.25 & 56.8 & 57.2 & 93.6 \\
3.125 & 70.6 & 73.8 & 100 \\
1.56 & 88.7 & 94.2 & 100 \\
\hline
\end{tabular}

5-FU: 5-Fluorouracil was used as a standard anticancer drug for comparison.

Table 7. Relative viability \% of colorectal carcinoma cell line (HCT-116) after treating by the tested essential oils.

\begin{tabular}{cccc}
\hline Concentration $\mu \mathrm{g} / \mathrm{ml}$ & 5-FU & Cinnamon essential oil & Lemon essential oil \\
\hline 100 & 7.4 & 7.8 & 45.7 \\
50 & 12.1 & 15.9 & 56.6 \\
25 & 19.8 & 23.1 & 71.3 \\
12.5 & 31.4 & 32.4 & 83.4 \\
6.25 & 49.9 & 55.6 & 96.5 \\
3.125 & 60.5 & 66.5 & 100 \\
1.56 & 73.6 & 87.8 & 100 \\
\hline
\end{tabular}

5-FU: 5-Fluorouracil was used as a standard anticancer drug for comparison.

Table 8. Cytotoxic activity of essential oils against human tumor cells.

\begin{tabular}{ccc}
\hline \multirow{2}{*}{ Compounds } & \multicolumn{2}{c}{ In vitro cytotoxicity IC50 $(\mu \mathrm{g} / \mathrm{ml}) \bullet$} \\
\cline { 2 - 3 } & HePG2 & HCT-116 \\
\hline 5-FU & $7.9 \pm 0.28$ & $5.3 \pm 0.31$ \\
Cinnamon & $8.6 \pm 0.49$ & $7.2 \pm 0.72$ \\
Lemon & $48.2 \pm 3.10$ & $72.6 \pm 4.16$ \\
\hline
\end{tabular}

-IC50 ( $\mu \mathrm{g} / \mathrm{ml}): 1$ - 10 (very strong). 11 - 20 (strong). 21- 50 (moderate). 51 - 100 (weak) and above 100 (non-cytotoxic); $\bullet 5-F U=5$-fluorouracil.

\section{Conclusion}

Since medicinal plants are important for pharmacological studies and medication progress, cinnamon and lemon essential oils are found very safe in cytotoxicity in vitro. Our study proved that antioxidant activity of essential oils was related to their chemical composition. The results obtained from this study showed that cinnamon and lemon essential oils can be considered good sources of natural antioxidants and can be used as natural food additives. This may be referred either to high proportion of the major ingredients or to cooperation between different oil constituents, so could be incorporated in the diet. 


\section{References}

[1] Frutos, M.J. and Hernandea-Herrero, J.A. (2005) Effect of Rosemary (Rosmarinus officinalis) on the Stability of Bread with an Oil, Garlic and Parsley Dressing. LWT-Food Science and Technology, 38, 651-655.

[2] Gomez-Estaca, J., Lacey, A.L.D., Lopez-Caballero, M.E., Gomez-Guillen, M.C. and Montero, P. (2010) Biodegradable Gelatin-Chitosan Films Incorporated with Essential Oils as Antimicrobial Agents for Fish Preservation. Food Microbiology, 27, 889-896. https://doi.org/10.1016/j.fm.2010.05.012

[3] Holley, R.A. and Patel, D. (2005) Improvement in Shelf-Life and Safety of Perishable Foods by Plant Essential Oils and Smoke Antimicrobials. Food Microbiology, 22, 273-292. https://doi.org/10.1016/j.fm.2004.08.006

[4] Lean, L.P. and Mohamed, S. (1999) Antioxidative and Antimycotic Effects of Turmeric, Lemongrass, Betel Leaves, Clove, Black Pepper Leaves and Garcinia atriviridis on Butter Cakes. Journal of the Science of Food and Agriculture, 79, 1817-1822. https://doi.org/10.1002/(SICI)1097-0010(199910)79:13<1817::AID-JSFA443>3.0.CO;2-L

[5] Nielsen, P.V. and Rios, R. (2000) Inhibition of Fungal Growth on Bread by Volatile Compounds from Spices and Herbs, and the Possible Application in Active Packaging, with Special Emphasis on Mustard Essential Oil. International Journal of Food Microbiology, 60, 219-229. https://doi.org/10.1016/S0168-1605(00)00343-3

[6] Bagamboula, C.F., Uyttendaele, M. and Debevere, J. (2004) Inhibitory Effect of Thyme and Basil Oils, Carvacrol, Thymol, Estragol, Linalool and $\rho$-Cymene towards Shigella sonnei and S. flexneri. Food Microbiology, 21, 33-42.

https://doi.org/10.1016/S0740-0020(03)00046-7

[7] Franz, C. and Novak, J. (2010) Sources of Essential Oils. In: Baser, K.H.C. and Buchbauer, G., Eds., Handbook of Essential Oils. Science, Technology, and Applications, CRC Press/ Taylor \& Francis Group, Boca Raton, 39-82.

[8] Bakkali, F., Averbeck, S., Averbeck, D. and Idaomar, M. (2008) Biological Effects of Essential Oils-A Review. Food and Chemical Toxicology, 46, 446-475.

https://doi.org/10.1016/j.fct.2007.09.106

[9] Teixeiraa, B., Marquesa, A., Ramosa, C., Nengc, N.R., Nogueirac, J. M.F., Saraivab, J.A. and Nunesa, M. L. (2013) Chemical Composition and Antibacterial and Antioxidant Properties of Commercial Essential Oils. Industrial Crops and Products, 43, 587-595. https://doi.org/10.1016/j.indcrop.2012.07.069

[10] Karpinska, M., Borowski, J. and Danowska-Oziewicz, M. (2001) The Use of Natural Antioxidants in Ready-to-Serve Food. Food Chemistry, 72, 5-9. https://doi.org/10.1016/S0308-8146(00)00171-0

[11] Rao, J. and McClements, D.J. (2012) Impact of Lemon Oil Composition on Formation and Stability of Model Food and Beverage Emulsions. Food Chemistry, 134, 749-757. https://doi.org/10.1016/j.foodchem.2012.02.174

[12] Noorolahi, Z., Sahari, M.A., Barzegar, M., Doraki, N. and Badi, H.N. (2013) Evaluation Antioxidant and Antimicrobial Effects of Cinnamon Essential Oil and Echinacea Extract in Kolompe. Journal of Medicinal Plants, 12, 14-28.

[13] Lin, Y.T., Labbe, R.G. and Shetty, K. (2005) Inhibition of Vibrio Parahemolyticus in Seafood Systems Using Oregano and Cranberry Phytochemical Synergies and Lactic Acid. Innovative Food Science and Emerging Technologies, 6, 453-458. https://doi.org/10.1016/j.ifset.2005.04.002

[14] Mathew, S. and Abraham, T.E. (2006) Studies on the Antioxidant Activities of Cinnamon (Cinnamomum verum) Bark Extracts, through Various in Vitro Models. Food Chemistry, 94, 520-528. https://doi.org/10.1016/j.foodchem.2004.11.043 
[15] Pattnaik, S., Padhan, D.K. and Jana, G.K. (2010) Evaluation of Cinnamon Oil, Peppermint Oil, Cardamom Oil \& Orange Oil as Antimicrobial Agents. Journal of Pharmacy Research, 3, 414-416.

[16] Donald, G. and Barceloux, M.D. (2008) Medical Toxicology of Natural Substances: Foods, Fungi, Medicinal Herbs, Toxic Plants, and Venomous Animals. John Wiley \& Sons, Hoboken, 39-43.

[17] Rozzaa, A.L., Moraesb, T.M., Kushimab, H., Tanimotoa, A., Marquesc, M.O.M., Bauabd, T.M., Hiruma-Limab, C.A. and Pellizzona, C.H. (2011) Gastroprotective Mechanisms of Citrus lemon (Rutaceae) Essential Oil and Its Majority Compounds Limonene and $\beta$-Pinene: Involvement of Heat-Shock Protein-70, Vasoactive Intestinal Peptide, Glutathione, Sulfhydryl Compounds, Nitric Oxide and Prostaglandin $\mathrm{E}_{2}$. Chemico-Biological Interactions, 189, 82-89. https://doi.org/10.1016/j.cbi.2010.09.031

[18] Adams, R.P. (2007) Identification of Eessential Oils Components by Gas Chromatography/Quadruple Mass Spectroscopy. 4th Edition, Allured Publishing Corporation, Carol Stream.

[19] Massada, Y. (1976) Analysis of Essential Oils by Gas Chromatography and Mass Sepectrometry. Wiley, New York.

[20] El-Gazzar, A.B.A., Youssef, M.M., Youssef, A.M.S., Abu-Hashem, A.A. and Badria, F.A. (2009) Design and Synthesis of Azolopyrimidoquinolines, Pyrimidoquinazolines as Anti-Oxidant, Anti-Inflammatory and Analgesic Activities. European Journal of Medicinal Chemistry, 44, 609-624. https://doi.org/10.1016/j.ejmech.2008.03.022

[21] Hawkey, P.M. and Lewis, D.A. (1994) Medical Bacteriology-A Practical Approach. Oxford University Press, Oxford, 181-194.

[22] Mosmann, T. (1983) Rapid Colorimetric Assay for Cellular Growth and Survival: Application to Proliferation and Cytotoxicity Assays. Journal of Immunological Methods, 65, 55-63. https://doi.org/10.1016/0022-1759(83)90303-4

[23] Graph Pad Prism Version 3.00 for Windows (1999) Graph Pad Software, San Diego.

[24] Kalaba, V. and Kalaba, D. (2014) Comparative Effects of Essential Oils on Growth of Escherichia coli Carpathian. Journal of Food Science and Technology, 6, 5-8.

[25] Popovic, G. and Milosevic, D.D. (2008) Effects of Ester Oil on Growth of Escherichia coli. Proceedings of Scientific Conference on "Ecological Truth" with International Participation, Sokobanja, 1-4 June 2008, 612-615.

[26] Elgendy, E.M. and Khayyat, S.A. (2014) Epoxide and Hydroperoxide Derived from Naturally Cinnamaldehyde and Its Schiff Base Derivatives. Asian Journal of Chemistry, 26, 6571-6574.

[27] Elgendy, E.M. (1998) Photooxygenation of Natural Limonene. Journal of Chinese Pharmaceutical Sciences, 50, 225-231.

[28] Halliwell, B. and Gutteridge, J.M.C. (2000) Free Radicals in Biology and Medicine. Oxford University Press, Oxford.

[29] Abd El-Baky, H.H. and El-Baroty, G.S. (2008) Chemical and Biological Evaluation of the Essential oil of Egyptian Moldavian Balm. International Journal of Essential Oil Therapeutics, 2, 76-81.

[30] Anwar, F., Ali, M., Hussain, A.I. and Shahid, M. (2009) Antioxidant and Antimicrobial Activities of Essential Oil and Extracts of Fennel (Foeniculum vulgare Mill.) Seeds from Pakistan. Flavour and Fragrance Journal, 24, 170-176. https://doi.org/10.1002/ffj.1929

[31] Frenkel, E.N., Huang, S.W., Kanner, J. and German, J.B. (1994) Interfacial Phenomena in the Evaluation of Antioxidants: Bulk Oils vs Emulsions. Journal of Agricultural and Food Chemistry, 42, 1054-1059. https://doi.org/10.1021/jf00041a001

[32] Koleva, I.I., van Beek, T.A., Linssen, J.P.H., de Groot, A. and Evstatieva, L.N. (2002) 
Screening of Plant Extracts for Antioxidant Activity: a Comparative Study on Three Testing Methods. Phytochemical Analysis, 13, 8-17. https://doi.org/10.1002/pca.611

[33] Puertas-Mejia, M., Hillebrand, S., Stashenko, E. and Winterhalter, P. (2002) In Vitro Radical Scavenging Activity of Essential Oils from Columbian Plants and Fractions from Oregano (Origanum vulgare L.) Essential Oil. Flavour and Fragrance Journal, 17, 380-384. https://doi.org/10.1002/ffj.1110

[34] Baratta, M.T., Dorman, H.J.D. and Deans, S.G. (1998) Chemical Composition, Antimicrobial and Antioxidative Activity of Laurel, Sage, Rosemary, Oregano and Coriander Essential Oils. Journal of Essential Oil Research, 10, 618-627. https://doi.org/10.1080/10412905.1998.9700989

[35] Baratta, M.T., Dorman, H.J.D., Deans, S.G., Figueiredo, A.C., Barosso, J.G. and Ruberto, G. (1998) Antimicrobial and Antioxidant Properties of Some Commercial Essential Oils. Flavour and Fragrance Journal, 13, 235-244. https://doi.org/10.1002/(SICI)1099-1026(1998070)13:4<235::AID-FFJ733>3.0.CO;2-T

[36] Ruberto, G., Baratta, M.T., Deans, S.G. and Dorman, H.J.D. (2000) Antioxidant and Antimicrobial Activity of Foeniculum vulgare and Crithmum maritimum Essential Oils. Planta Medica, 66, 687-693. https://doi.org/10.1055/s-2000-9773

[37] Dorman, H.J.D., Figueiredo, A.C., Barroso, J.G. and Deans, S.G. (2000) In Vitro Evaluation of Antioxidant Activity of Essential Oils and Their Components. Flavour and Fragrance Journal, 15, 12-16. https://doi.org/10.1002/(SICI)1099-1026(200001/02)15:1<12::AID-FFJ858>3.0.CO;2-V

[38] Ruberto, G., Baratta, M.T., Sari, M. and Kaâbeche, M. (2002) Chemical Composition and Antioxidant Activity of Essential Oils from Algerian Origanum glandulosum Desf. Flavour and Fragrance Journal, 17, 251-254. https://doi.org/10.1002/ffj.1101

[39] Tomaino, A., Cimino, F., Zimbalatti, V., Venuti, V., Sulfaro, V., De Pasquale, A. and Saija, A. (2005) Influence of Heating on Antioxidant Activity and the Chemical Composition of Some Spice Essential Oils. Food Chemistry, 89, 549-554. https://doi.org/10.1016/j.foodchem.2004.03.011

[40] Politeo, O., Juki, M. and Milo, M. (2006) Chemical Composition and Antioxidant Activity of Essential Oils of Twelve Spice Plants. Croatica Chemica Acta, 79, 545-552.

[41] Frenkel, E.N. (1993) In Search of Better Methods to Evaluate Natural Antioxidants and Oxidative Stability in Food Lipids. Trends in Food Science \& Technology, 4, 220-225. https://doi.org/10.1016/0924-2244(93)90155-4

[42] Pajero, I., Viladomat, F., Bastida, J., Rosas-Romero, A., Saavedra, G., Murcia, M.A., Jimenez, A.M. and Codina, C. (2003) Investigation of Bolivian Plant Extracts for Their Radical Scavenging Activity and Antioxidant Activity. Life Sciences, 73, 1667-1681. https://doi.org/10.1016/S0024-3205(03)00488-0

[43] Abdalla, A.E. and Roozen, J.P. (1999) Effect of Plant Extracts on the Oxidative Stability of Sunflower Oil and Emulsion. Food Chemistry, 64, 323-329. https://doi.org/10.1016/S0308-8146(98)00112-5

[44] Inouye, S., Takizawa, T. and Yamaguchi, H. (2001) Antibacterial Activity of Essential Oils and Their Major Constituents against Respiratory Tract Pathogens by Gaseous Contact. Journal of Antimicrobial Chemotherapy, 47, 565-573. https://doi.org/10.1093/jac/47.5.565

[45] Inouye, S., Yamaguchi, H. and Takizawa, T. (2001) Screening of the Antibacterial Effects of a Variety of Essential Oils on Respiratory Tract Pathogens, Using a Modified Dilution Assay Method. Journal of Infection and Chemotherapy, 7, 251-254. https://doi.org/10.1007/s101560170022

[46] Lopez, P., Sanchez, C., Batlle, R. and Nerin, C. (2005) Solid and Vapor Phase Antimicrobial Activity of Six Essential Oils: Susceptibility of Selected Foodborne Bacteria and Fungal 
Strains. Journal of Agricultural and Food Chemistry, 53, 6939-6946.

https://doi.org/10.1021/jf050709v

[47] Yan, H.C., Hong, P., Yu, Z.Z. and Jing, S. (2010) Evaluation of Antioxidant and Antitumor Activities of Lemon Essential Oil. Journal of Medicinal Plants Research, 4, 1910-1915.

[48] Denizot, F. and Lang, R. (1986) Rapid Colorimetric Assay for Cell Growth and Survival. Journal of Immunological Methods, 89, 271-277. https://doi.org/10.1016/0022-1759(86)90368-6

[49] Mauceri, H.J., Hanna, N.N., Beckett, M.A., Gorski, D.H., Staba, M.J., Stellato, K.A., Bigelow, K., Heimann, R., Gately, S., Dhanabal, M., Soff, G.A., Sukhatme, V.P., Kufe, D.W. and Weichselbaum, R.R. (1998) Combined Effects of Agiostatin and Ionizing Radiation in Antitumour Therapy. Nature, 394, 287-291. https://doi.org/10.1038/28412

Submit or recommend next manuscript to SCIRP and we will provide best service for you:

Accepting pre-submission inquiries through Email, Facebook, LinkedIn, Twitter, etc. A wide selection of journals (inclusive of 9 subjects, more than 200 journals)

Providing 24-hour high-quality service

User-friendly online submission system

Fair and swift peer-review system

Efficient typesetting and proofreading procedure

Display of the result of downloads and visits, as well as the number of cited articles

Maximum dissemination of your research work

Submit your manuscript at: http://papersubmission.scirp.org/

Or contact fns@scirp.org 